METODY ZBIERANIA

I ANALIZY DANYCH

W BADANIACH EDUKACYJNYCH

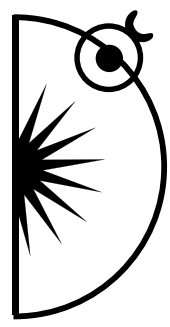

Mariola Chomczyńska-Rubacha, Krzysztof Rubacha

\title{
Test Poczucia Skuteczności. Opracowanie teoretyczne i psychometryczne Pracowni Narzędzi Badawczych Komitetu Nauk Pedagogicznych PAN*
}

DOI: http://dx.doi.org/10.12775/PBE.2013.007

\section{Wprowadzenie}

Prezentowany podręcznik do Testu Poczucia Skuteczności jest pierwszym wydanym przez Pracownię Narzędzi Badawczych KNP PAN. Podręcznik prezentuje wyniki badań standaryzacyjnych, rekonstruujących proces budowania narzędzia oraz kolejne etapy jego empirycznej weryfikacji. Zawiera także informacje o warunkach, w jakich należy stosować TPS, by zapewnić badaniu wysoki poziom trafności wewnętrznej. Badania konstrukcyjne i walidacyjne trwały sześć lat i zostały oparte na niemal 1,5 tys. próbce losowej. W latach 2006-2012 używano TPS w różnych programach badawczych, które nadal testowały jego trafność oraz dostarczały materiału do aktualizowania norm dla populacji ogólnej i populacji nauczycieli. Podręcznik rozpoczyna się od analizy podstaw teoretycznych poczucia skuteczności, zmiennej wywodzącej się z paradygmatu funkcjonalistycznego, z teorii społeczno-poznawczej. Ponieważ jak będzie można to śledzić na kolejnych stronach tekstu - konstrukt teoretyczny, stanowiący podstawę operacjonalizacji został pozytywnie zweryfikowany,

\footnotetext{
* (c) M. Chomczyńska-Rubacha, K. Rubacha.
} 
tę pierwszą część podręcznika należy też traktować jako kierunek teoretycznej interpretacji wyników, które uzyskują osoby badane. W drugiej części zaprezentowano wyniki szacowania mocy dyskryminacyjnej tych pozycji TPS, które zostały zbudowane podczas pierwszej operacjonalizacji. Były to 32 pozycje, zawierające wskaźniki definicyjno-inferencyjne opisanych w części pierwszej konstruktów teoretycznych. Wyniki tych analiz pokazano szczegółowo w odniesieniu do 17 pozycji, a więc tych, które pozytywnie przeszły etap weryfikacji stopnia, w jakim różnicują populację generalną. W trzeciej części pokazano rezultaty szacowania dokładności, z jaką TPS mierzy swój konstrukt teoretyczny. W czwartej - chyba najważniejszej części - zamieszczono dane weryfikujące różne rodzaje trafności TPS: diagnostyczną, prognostyczną oraz cztery rodzaje trafności teoretycznej. To ważne dane, ponieważ zapewniają trafność wewnętrzną badań, w których TPS jest używany. W piątej części znajdują się normy stenowe obliczone dla populacji ogólnej i populacji nauczycieli. Opisując badania dotyczące mocy dyskryminacyjnej, rzetelności, trafności i normalizacji TPS ${ }^{1}$, odwoływano się dwóch analiz: 2006 r. i 2012 r. Analiza z 2012 r. jest kluczowa, ponieważ jest już drugą analizą, która pozytywnie weryfikuję analizę pierwszą, oraz została oparta na najświeższych danych.

\section{Podstawy teoretyczne*}

Działanie najczęściej jest poprzedzone myśleniem i emocjami. Procesy te prowadzą do określenia celów i standardów działania. Nie zanikają one także w trakcie działania, przeciwnie towarzyszą mu i stanowią podstawę dla jego kontynuacji, modyfikacji lub wstrzymania. Zjawiskiem, któremu przypisuje się silny wpływ zarówno na myślenie, emocje, jak i samo działanie jest poczucie własnej skuteczności (self-efficacy), definiowane najogólniej jako przekonanie jednostki na temat osobistych możliwości spełnienia różnorodnych warunków zadania, prowadzących do osiągnięcia zamierzonych rezultatów (Bussey, Bandura 1999, s. 691). Tak rozumiane poczucie własnej skuteczności stanowi czynnik pośredniczący pomiędzy celami, a wysiłkami ukierunkowanymi na ich osiągnięcie (Pervin, John 2002, s. 481). Można zatem traktować poczucie włas-

\footnotetext{
* Ten tekst jest zmienioną częścią wcześniej opublikowanej pracy: Poczucie własnej skuteczności nauczycieli. Podstawy teoretyczne, pomiari obszary badań (Chomczyńska-Rubacha, Rubacha 2006).

1 Ponieważ omawiamy sześcioletnie badania, część danych i część prezentowanych analiz dotyczących tych fragmentów niniejszego tekstu była już wcześniej publikowana: Chomczyńska-Rubacha, Rubacha 2006, 2007.
} 
nej skuteczności jako zmienną odpowiedzialną za powodzenie/niepowodzenie działania. Nie można przy tym mylić poczucia własnej skuteczności z oczekiwaniami co do rezultatu działania. Poczucie własnej skuteczności nie dotyczy pewności, że działanie zakończy się osiągnięciem określonego standardu (wiem, że swoim wykładem wzbudzę ciekawość poznawczą uczniów), dotyczy natomiast pewności (przekonania), że jest się w stanie taki standard osiągnąć (mogę wzbudzić ciekawość poznawczą uczniów). Waga tego przekonania polega na tym, że jest ono motywem do podjęcia działania. Niewiara we własne możliwości blokuje aktywność na rzecz osiągania jakiegoś standardu (Kaplan 1990, s. 267). Oczekiwanie rezultatu pojawia się zatem pomiędzy działaniem a jego wynikiem, podczas gdy oczekiwanie własnej skuteczności - jeszcze przed podjęciem działania (por. Oleś 2003, s. 214). Można zatem powiedzieć, że poczucie własnej skuteczności jest zmienną natury formalnej w takim sensie, że nie dotyczy treści konkretnego działania, lecz percepcji siebie jako sprawcy w ogóle. Pogląd ten, choć bezpośrednio wynika z wcześniejszych analiz, bywa przedmiotem sporów. A. Bandura, którego należy najsilniej kojarzyć z pojęciem poczucia własnej skuteczności (1994, 1999), dokonywał pomiaru tej zmiennej w warunkach eksperymentalnych, czyli w konkretnych sytuacjach. Wyniki jego badań należy więc interpretować w odniesieniu do zadań i określonych kontekstów, nie zaś w odniesieniu do zasobów osobistych jednostki, możliwych do wykorzystania w wielu kontekstach. Podejście A. Bandury krytykuje szczególnie M. E. P. Seligman (za: Pervin, John 2002, s. 523), twierdząc, że kontekstualizacja poczucia własnej skuteczności ogranicza jego moc wyjaśniającą w odniesieniu do szerszych aspektów zachowania. Można do tego dodać, że jest w konflikcie z rozróżnieniem, jakiego A. Bandura dokonał między poczuciem własnej skuteczności a oczekiwaniem pozytywnego rezultatu działania. Wyraźnie oddzielił te dwa zjawiska i pokazywał, że są względnie niezależne. To znaczy, że fakt, iż oczekujemy sukcesu, funkcjonuje na innym poziomie niż wiara w możliwość jego osiągnięcia (Bandura 1999, s. 692). Takie myślenie kontrastuje z założeniem o sytuacyjnej zmienności poczucia własnej skuteczności, bo jednym z jego kryteriów musiałoby być oczekiwanie sukcesu albo porażki. Ten zresztą moment jest także przedmiotem analiz krytycznych. A. Bandura spotyka się z zarzutem, że zbyt pochopnie odrzucił powiązanie poczucia własnej skuteczności z oczekiwaniem rezultatu. Krytycy piszą, że skoro wykonanie zadania prawie zawsze jest związane $\mathrm{z}$ wynikiem, to przekonania o własnej skuteczności powinny blisko wiązać się z oczekiwaniami. Ten zarzut jednak A. Bandura falsyfikuje, pokazując, że jest dużo sytuacji, gdy oczekiwania są tylko częściowo pod kontrolą podmiotu działającego oraz że - zgodnie 
z wynikami badań - oczekiwania rezultatu nie są tak dobrym predyktorem działania, jak poczucie własnej skuteczności (Pervin, John 2002, s. 522). I choć zakończenie tego sporu wymaga nagromadzenia nowych wyników badań, tok rozumowania A. Bandury wyraźnie kontrastuje z postulatem sytuacyjnego badania poczucia własnej skuteczności. Wracając do zasadniczego wątku analizy, można powiedzieć, że jeśli uznamy za A. Bandurą, że poczucie własnej skuteczności jest cennym predyktorem zachowania, musimy je także traktować jako element zasobów osobistych jednostki, a nie tylko jako czynnik sytuacyjnie modyfikujący działanie. A to oznacza wykroczenie poza zasięg analiz A. Bandury. Autor ten bowiem operacjonalizował poczucie własnej skuteczności w kategoriach empirycznych, a nie teoretycznych. Wskaźnikiem był sąd osoby badanej na temat przekonania o własnej skuteczności w danej sytuacji, wypowiedziany przed podjęciem działania (tzw. badania mikroanalityczne) Nie można jednak postąpić analogicznie, jeśli traktuje się poczucie własnej skuteczności jako konstrukt teoretyczny opisujący psychiczne zasoby jednostki. Należy raczej odtworzyć jego strukturę i operacjonalizować ją przy pomocy wskaźników definicyjnych (kwestionariusze). Jakie zatem dyspozycje jednostki składają się na zgeneralizowane poczucie własnej skuteczności? Odpowiedzi na to pytanie należy szukać w analizach teoretycznych i wynikach badań dotyczących indywidualnych uwarunkowań skutecznego działania. W. Mischel i Y. Schoda (1988, s. 688-696) prowadzili długoletnie badania nad poznawczymi mechanizmami działania dzieci w wieku przedszkolnym i w okresie adolescencji. Główną zmienną tych badań było odraczanie gratyfikacji, definiowane jako umiejętność rezygnowania z nagrody do czasu osiągnięcia wysokiego standardu działania. Idea tych badań podłużnych polegała na notowaniu czasu odraczania gratyfikacji u przedszkolaków i korelowaniu go z opisem działania tych dzieci, gdy wkroczyły w fazę wczesnej adolescencji. Ujemne korelacje uzyskano dla takich działań, jak: uleganie łatwo przychodzącym nagrodom, przerywanie działania, które nie przynosiło szybkiego sukcesu, natychmiastowe podejmowanie decyzji (najczęściej niewłaściwej), brak samokontroli w sytuacji pokusy. Dodatnie korelacje natomiast pojawiały się przy takich zachowaniach: koncentracja na zadaniu, wytrwałość w działaniu, samokontrola w sytuacji powtarzającego się niepowodzenia, wysoka motywacja. Jeśli przyjąć, że pośrednie i bezpośrednie doświadczanie stanowi zasadniczy mechanizm uczenia się, to można utrzymać hipotezę o związku między powodzeniem w osiąganiu wysokich standardów działania, a samooceną i wiarą we własne siły w kolejnych próbach tego rodzaju. Słowem, badania te definiują umiejętność odraczania gratyfikacji jako składnik nie tylko sprawnego działania, ale 
także poczucia własnej skuteczności. K. Obuchowski pisze nawet o „dalekiej skuteczności działań” jako rezultacie rozwoju takich kompetencji jak właśnie rezygnacja z bezpośrednich gratyfikacji na rzecz dążenia do celu (1985, s. 132). $\mathrm{W}$ podobnym duchu analizy nad tendencją do samorealizacji prowadzi A. Strzałecki, wyraźnie łącząc poczucie skuteczności osiągania celów i zadań z odraczaniem bliskich czasowo nagród (1989, s. 76). Chodzi tutaj najprawdopodobniej o budowanie przekonania na temat własnej skuteczności na zweryfikowanej w doświadczeniu samowiedzy o możliwościach, jakie jednostka posiada w zakresie motywacji do działania. W literaturze przedmiotu szczególnie podkreśla się dwa aspekty motywacji: motywację rozwojową oraz wytrwałość w działaniu. Jeśli szukamy podstaw poczucia własnej skuteczności, to doświadczenia w zakresie realizacji tzw. zadań dalekich, a więc nastawionych na podejmowanie osobistych celów rozwojowych okazują się, zdaniem K. Obuchowskiego (1985, s. 201), czynnikami sprawnego funkcjonowania, opartego na umiejętności dostrajania jednostki do własnych przewidywań. Tego typu doświadczenia motywacyjne wzmagają wytrwałość w działaniu, która dostarcza jednostce informacji zwrotnych budujących wiarę we własne siły. Częste porzucanie celów dalekich natomiast destabilizuje pozytywne myślenie o sobie w kategoriach zdolności do poświęceń. Widać zatem wyraźnie, że takie zmienne, jak: umiejętność odraczania gratyfikacji, wiara we własne siły, motywacja rozwojowa oraz wytrwałość w działaniu, budują przestrzeń dla poczucia własnej skuteczności. Można hipotetycznie przyjmować, że poczucie to pojawia się jako rezultat autoanalizy doświadczenia związanego z motywacją do działania (zasoby motywacyjne). Czy istnieje przestrzeń do falsyfikacji takiej hipotezy? Stanowi ją pogląd A. Bandury twierdzącego, że bywają badani, którzy ujawniają nierealistycznie wyolbrzymione poczucie własnej skuteczności, niejako oderwane od osobistych doświadczeń motywacyjnych (za: Oleś 2003, s. 215). Autor jednak nie wyjaśnia tego fenomenu w swoich badaniach. Można natomiast domniemywać, że takie poczucie będzie oparte na innego rodzaju doświadczeniu niż motywacyjne. A. Bandura pisze o wpływie odnoszonych sukcesów na percepcję własnej skuteczności (1999, s. 692). Na ten problem jednak należy patrzeć w perspektywie indywidualnych uwarunkowań powodzenia w działaniu. Dane z badań prakseologicznych wskazują na umiejętność przekładania celów na program działania jako zmienną wzmacniającą skuteczność działań. A. Strzałecki opisuje zjawisko „aktywnego stosunku do problemu”, na które właśnie składają się heurystyczne strategie analizowania i planowania możliwych działań koniecznych do wykonania zadania czy rozwiązania problemu (1989, s. 167). Często powodzenie w działaniu zależy od liczby i trafności stosowa- 
nych reguł przekładania ogólnych celów na dyrektywy praktyczne. Takie doświadczenie może być generalizowane na późniejsze poczucie własnej skuteczności bezpośrednio lub pośrednio - przez wzmacnianie odporności na frustrację i stres. Planowanie zadań i reguł sprzyja rozpoznawaniu i opanowywaniu nieznanych zjawisk, budzących swą nowością obawy i lęk (por. Strzałecki 1989, s. 155).

Jeśli analizujemy indywidualne uwarunkowania powodzenia $\mathrm{w}$ działaniu, trafiamy na analizy W. Łukaszewskiego, który wprowadził pojęcie poczucia sprawstwa, rozumianego jako zdolność do postrzegania siebie jako człowieka przekonanego o własnych możliwościach ingerowania w zdarzenia w taki sposób, aby zmienić ich przebieg i skutki (1984, s. 435). Pomimo podobieństw jest to pojęcie węższe od poczucia własnej skuteczności. Nawiązuje bowiem głównie do wysokiej samooceny i jej związku z zachowaniem. Jednostka posiadająca silne natężenie tej dyspozycji wierzy, że to, co robi, zależy od niej samej i różnymi strategiami może wpływać na zdarzenia. Autor pisał o tym w kontekście ustosunkowania się jednostki wobec presji kulturowo-społecznych, które mogą sterować życiem człowieka, eliminując jego udział. Patrząc na tę zmienną z perspektywy poczucia własnej skuteczności, można odnieść wrażenie, że jest ona niezbędnym warunkiem podejmowania aktywności wszędzie tam, gdzie sytuacja wyjściowa wymaga ingerencji własnych zasobów w odwrócenie niekorzystnego wpływu wydarzeń. Przekonanie, że jednostka, wkraczając w określoną sytuację, jest w stanie ją zmodyfikować, wynika pośrednio z faktu, że człowiek posiada własną wizję sytuacji. Ta wizja z kolei jest możliwa, jeśli jednostka kieruje się autonomicznymi, wewnętrznymi standardami. Mowa zatem o wewnątrzsterowności jako źródle lokowania przekonań i wartości, którymi człowiek motywuje swoje działanie (Strzałecki 1989, s. 163; Rubacha 2000, s. 150). Taka właśnie orientacja w wartościowaniu stanowi doświadczenie, które może budować poczucie własnej skuteczności, ponieważ przekonanie o nim wyrasta $\mathrm{z}$ osobistych zasobów jednostki, w tym przypadku z autonomicznych standardów.

Można zatem powiedzieć, że wśród kolejnych komponentów poczucia własnej skuteczności umieścimy umiejętność przekładania celów na program działania, odporność na frustrację i stres, poczucie sprawstwa oraz wewnątrzsterowność. Wykonane analizy teoretyczne umożliwiają również objęcie tych dyspozycji ogólniejszą kategorią zasobów poznawczo-działaniowych jednostki.

Ostatecznie przyjmujemy, że poczucie własnej skuteczności powstaje na podstawie osobistych doświadczeń jednostki w zakresie dysponowania zasoba- 
mi motywacyjnymi i poznawczo-działaniowymi. Na te pierwsze składają się: umiejętność odraczania gratyfikacji, wiara we własne siły, motywacja rozwojowa i wytrwałość w działaniu. Natomiast zasoby poznawczo-działaniowe budują takie zmienne, jak: umiejętność przekładania celów na program działania, odporność na frustrację i stres, poczucie sprawstwa oraz wewnątrzsterowność. Zaprezentowane ujęcie teoretyczne stanowi bazę dla operacjonalizacji poczucia własnej skuteczności w postaci kwestionariusza testu.

\section{Zasady operacjonalizacji}

Koncentrujemy się na poczuciu własnej skuteczności jako zmiennej zasobów osobistych jednostki, a nie zmiennej grupującej właściwości sytuacji społecznych. Takie podejście teoretyczne pozwala na operacjonalizowanie pojęcia poczucia własnej skuteczności w postaci testu, mierzącego zgeneralizowany samoopis badanych. Za punkt wyjścia przyjęliśmy opisane powyżej, traktowane jako osiowe, właściwości jednostki konstytuujące jej przeświadczenie o skuteczności podejmowanych działań. Są to zmienne, które można hipotetycznie ułożyć w dwie grupy zasobów osobistych jednostki: zasoby poznawczo-działaniowe oraz zasoby motywacyjne. Do tych kategorii teoretycznych układaliśmy zdania, zawierające ich wskaźniki w odniesieniu do osobistego doświadczenia i samowiedzy badanych. Oto przykłady operacjonalizacji dwóch kategorii teoretycznych: wewnątrzsterowności i wytrwałości w działaniu.

\section{„Nawet gdy inni we mnie wątpią, ja z uporem dążę do celu"}

Jeśli badany odpowiada „zdecydowanie tak” lub „raczej tak”, to mamy wskaźnik wewnątrzsterowności. Jeśli odpowiada „zdecydowanie nie” lub „raczej nie", ujawnia się wskaźnik braku wewnątrzsterowności. Zdanie to nawiązuje do doświadczeń ludzi w sytuacji, kiedy coś robią, a inni uważają to za bezcelowe lub nie wierzą, że im się uda. Zdanie to także nawiązuje do definicji wewnątrzsterowności: mówi bowiem o realizowaniu własnej, autonomicznej decyzji o finalizacji podjętego działania. Świat zewnętrzny nie może w tym przeszkodzić. Jeśli badany ma takie doświadczenia, jak pokazane w tym zdaniu, to ujawnia wewnątrzsterowność, jeśli natomiast w podobnych sytuacjach się zniechęca, to ulega wpływom zewnętrznym. 


\section{„Gdyby nie to, że niektóre zadania zbyt silnie wystawiały na próbę moją cierpliwość, zakończył(a)bym je sukcesem"}

Jeśli osoba odpowiada „zdecydowanie tak” lub „raczej tak”, to mamy wskaźnik braku wytrwałości w działaniu. Jeśli odpowiada „zdecydowanie nie” lub „raczej nie” ujawnia się wskaźnik wytrwałości w działaniu. Zdanie to odnosi się do doświadczeń ludzi w sytuacji, gdy zadanie jest trudne lub wymagające czasu, kiedy nie wystarcza cierpliwości, kiedy chciałoby się już zmienić zajęcie, np. stan taki może się pojawić, gdy musimy pomalować 600 słupków, a jesteśmy jeszcze przed połową, lub gdy kolejne próby wythumaczenia komuś czegoś dla nas oczywistego nie przynoszą skutku. Zdanie to także nawiązuje do definicji wytrwałości w działaniu: mówi bowiem o możliwości utrzymania długotrwałej koncentracji na jakimś zadaniu (por. K. Rubacha 2008, s. 65). Takich zdań zawierających, o wskaźnikach wyżej opisanych kategorii teoretycznych, skonstruowano 32. Powstała więc pierwsza wersja operacjonalizacji, z której selekcjonowano pozycje do eksperymentalnej wersji TPS.

Test Poczucia Skuteczności był konstruowany w odniesieniu do populacji ogólnej. Niemniej jednak pierwsze etapy jego empirycznej weryfikacji odbywały się na danych pochodzących z badań nad nauczycielami. Są to badania z lat 2005-2006. Na ich podstawie powstała pierwsza wersja testu, na podstawie której następnie zbadano około 1000 osób, z czego większość nie miała związku z zawodem nauczycielskim ani żadnym szczególnym zawodem. Osoby te reprezentowały populację ogólną. Bazując na tych właśnie danych, w 2012 r. po raz drugi przeprowadzono analizy standaryzacyjne.

\section{Moc dyskryminacyjna pozycji testu}

Stopień, w jakim poszczególne pozycje testu różnicują badaną próbkę, oszacowaliśmy przy pomocy współczynnika korelacji dwuseryjnej (rbi). Analizy wykonano dwa razy: w 2006 r. i 2012 r. W pierwszym badaniu, mając do dyspozycji próbkę 286 nauczycieli, wybraliśmy do analizy po $27 \%$ wyników najniższych i najwyższych (dolna i górna grupa). Do wersji eksperymentalnej testu włączyliśmy 17 pozycji, które mieściły się w przedziale od .26 do .86 $(\mathrm{p}<.001)$, w którym średnia wynosiła .50 , a mediana .48 . W drugiej analizie wykorzystano wyniki badań z lat 2007-2012 przeprowadzonych na populacji kobiet i mężczyzn. Mając do dyspozycji 370 wyników, powtórzono procedurę $\mathrm{z}$ pierwszego pomiaru, ale jedynie $\mathrm{w}$ odniesieniu do 17 pozycji wyłonionych jako trafne po pierwszym badaniu. Ten pomiar pełnił dwie funkcje: zbadanie 
próbki z populacji ogólnej oraz zweryfikowanie pierwszego pomiaru sprzed 6 lat. Wartości współczynnika korelacji dwuseryjnej mieściły się w przedziale $.29-.77(\mathrm{p}<.05)$, ze średnią $.47 \mathrm{i}$ medianą .37 . W tabeli 1 podajemy wartości rbi dla poszczególnych pozycji testu z przypisaniem do kategorii teoretycznych, które operacjonalizują.

Tabela 1. Wartości współczynników korelacji dwuseryjnej pozycji TPS wraz z kategoriami teoretycznymi, które operacjonalizują

\begin{tabular}{|c|c|c|c|}
\hline \multicolumn{2}{|r|}{ [numer pozycji w teście/kategoria teoretyczna] } & $\begin{array}{c}\mathrm{Rbi} \\
2006\end{array}$ & $\begin{array}{c}\mathrm{Rbi} \\
2012\end{array}$ \\
\hline 1 & 2 & 3 & 4 \\
\hline $1 / 5$ & $\begin{array}{l}\text { Gdy zadanie wydaje mi się zbyt trudne, to nie tracę czasu i zabieram się } \\
\text { za inne sprawy. }\end{array}$ & .48 & .37 \\
\hline $2 / 3$ & $\begin{array}{l}\text { Jest wiele sytuacji życiowych, które są tak skomplikowane, że można się } \\
\text { tylko wycofać. }\end{array}$ & .45 & .51 \\
\hline $3 / 8$ & Nawet gdy inni wątpią w moje możliwości, ja z uporem dążę do celu. & .64 & .52 \\
\hline $4 / 1$ & $\begin{array}{l}\text { To, co mnie zniechęca, by doprowadzić trudne zadania do końca, to } \\
\text { konieczność rezygnacji ze zbyt wielu przyjemności. }\end{array}$ & .32 & .35 \\
\hline $5 / 7$ & $\begin{array}{l}\text { Nie warto trwonić czasu, jeśli wydaje się, że zadanie do wykonania } \\
\text { przekracza moje możliwości. }\end{array}$ & .28 & .37 \\
\hline $6 / 8$ & $\begin{array}{l}\text { Granicą wiary we własnej siły są informacje o tym, jak nas spostrzegają } \\
\text { inni. }\end{array}$ & .38 & .29 \\
\hline $7 / 3$ & $\begin{array}{l}\text { Inni ludzie, obserwując moje zachowanie, mogliby pomyśleć, że jestem } \\
\text { pesymistą. }\end{array}$ & .34 & .35 \\
\hline $8 / 6$ & Jestem osobą, która ma na swoim koncie więcej porażek niż sukcesów. & .43 & .36 \\
\hline $9 / 1$ & $\begin{array}{l}\text { Zdarza się, że zarzucam realizowanie celów, gdy na efekty trzeba czekać } \\
\text { bardzo długo. }\end{array}$ & .83 & .72 \\
\hline $10 / 4$ & $\begin{array}{l}\text { Byłbym o wiele skuteczniejszy w działaniu, gdyby nie stres, który mi } \\
\text { towarzyszy. }\end{array}$ & .74 & .74 \\
\hline $11 / 4$ & $\begin{array}{l}\text { Efektywność mojego działania zmniejsza się w okresach, gdy odnoszę } \\
\text { etapowe porażki. }\end{array}$ & .55 & .42 \\
\hline $12 / 2$ & Nie żal mi czasu na opracowywanie strategii działania. & .26 & .31 \\
\hline $13 / 2$ & $\begin{array}{l}\text { Zamiast tracić czas na rozważanie różnych wariantów działania, po prostu } \\
\text { działam. }\end{array}$ & .77 & .59 \\
\hline $14 / 2$ & Cieszy mnie tylko taki sukces, który jest adekwatny do nakładów pracy. & .69 & .62 \\
\hline
\end{tabular}


cd. tab. 1

\begin{tabular}{|c|l|c|c|}
\hline 1 & \multicolumn{1}{|c|}{2} & 3 & 4 \\
\hline $15 / 7$ & $\begin{array}{l}\text { Wolę zadania, co do których mam pewność, że zakończą się sukcesem, niż } \\
\text { zadania, które takiej pewności nie dają. }\end{array}$ & .28 & .32 \\
\hline $16 / 6$ & $\begin{array}{l}\text { Gdy nie czuję, że w pełni wpływam na to, co robię, mam trudności } \\
\text { z kontynuowaniem działania. }\end{array}$ & .86 & .77 \\
\hline $17 / 5$ & $\begin{array}{l}\text { Gdyby nie to, że niektóre zadania zbyt silnie wystawiały na próbę moją } \\
\text { cierpliwość, zakończyłbym je sukcesem. }\end{array}$ & .35 & .36 \\
\hline
\end{tabular}

Oznaczenia kategorii teoretycznych: liczba za ukośnikiem w pierwszej kolumnie: 1 - umiejętność odraczania gratyfikacji, 2 - umiejętność przekładnia celów na program działania, 3 - wiara we własne siły, 4 - odporność na frustrację i stres, 5 - wytrwałość w działaniu, 6 - poczucie sprawstwa, 7 - motywacja rozwojowa, 8 - wewnątrzsterowność.

Źródło: badania własne.

\section{Rzetelność}

Dokładność, z jaką test mierzy poczucie własnej skuteczności oszacowano metodą Spearmana-Browna (za: Brzeziński 1984, s. 189). Na danych z 2006 r. wykonano następujące obliczenia:

$$
\mathrm{rtt}=\frac{\mathrm{n} \mathrm{\textrm {r } ^ { \overline { \mathrm { i } } } \mathrm { t }}-1}{(\mathrm{n}-1) \mathrm{r}^{\overline{\mathrm{iit}}}}
$$

gdzie:

$\mathrm{r}^{2}$ it - kwadrat średniej korelacji pozycji z ogólnym wynikiem testu

$\mathrm{n}$ - liczba pozycji w teście

rtt - współczynnik Spearmana-Browna

Po podstawieniu danych do wzoru:

$$
\mathrm{rtt}=\frac{(17 \times .258)-1}{16 \times .258}
$$

otrzymano $\mathrm{rtt}=.82$ 
Analogicznie postąpiono z danymi z 2012 r. Wskaźnik rzetelności oszacowano na poziomie .78. Uzyskane z obliczeń wartości stanowią wystarczający wskaźnik rzetelności naszego testu jako całości. Obliczenia wykonano, posługując się danymi z analizy mocy dyskryminacyjnej. Warto powiedzieć, że dolną granicą rzetelności testu, jaką przyjmuje się najczęściej, jest .75. Czy zatem rzetelność z drugiego pomiaru nie wydaje się granicznie niska? Gdyby test był zbudowany z kilku skal i interpretacja wyników opierałyby się na subtelnych porównaniach wyników poszczególnych skal, można by było mieć takie wątpliwości. W naszej jednak sytuacji wartość .78 - choć niezbyt wysoka - jest wystarczająca. Argument ten wzmacnia późniejsza analiza. W kolejnym bowiem etapie standaryzacji testu (2006), przy okazji estymacji trafności teoretycznej TPS, zbadano rzetelność jego poszczególnych pozycji na innej już próbce 150 nauczycieli. Zastosowano formułę Alfa Cronbacha, która przyniosła nieco wyższe wskaźniki rzetelności ogólnej alfa $=.88$, gdzie poszczególne pozycje mieściły się w przedziale alfa (.87-.89). Podobnie postąpiono w 2012 r., kiedy to z próbki 220 osób badanych (nie będących nauczycielami) wyliczono wartości alfa w przedziale (.86-89), z alfa rzetelności ogólnej .87. Ostatecznie można przyjąć, że TPS, zarówno dla populacji nauczycieli, jak i populacji ogólnej posiada pozytywnie zweryfikowaną rzetelność.

\section{Trafność}

Jaką odpowiedź możemy otrzymać, pytając o trafność testu? Możemy dowiedzieć się, czy test mierzy to, co ma mierzyć, zarówno w sensie diagnostycznym, prognostycznym, jak i teoretycznym. W przypadku trafności diagnostycznej potrzebne jest kryterium zewnętrzne, do którego porówna się wyniki naszych pomiarów. Powinien to być pomiar innym testem, którego trafność nie budzi zastrzeżeń. Trafność prognostyczna natomiast wymaga powtórzenia pomiaru po upływie nie więcej niż 30 dni na tej samej próbce badanych. W obu przypadkach wysokie współczynniki korelacji pomiędzy pomiarami będą wskaźnikami trafności, odpowiednio diagnostycznej i prognostycznej. Trafność diagnostyczną weryfikowano dwa razy: w 2007 r. i 2012 r. W pierwszym pomiarze jako kryterium zewnętrzne wybrano test Uogólnionej Własnej Skuteczności w opracowaniu Z. Juczyńskiego (2001). Współczynnik korelacji liniowej Pearsona między tym testem a TPS wynosił .78, $\mathrm{p}<.05, \mathrm{~N}=198$. Związek między zmiennymi był, przed wykonaniem obliczeń, zweryfikowany jako liniowy. Warto dodać, że test Z. Juczyńskiego okazał się trafny w sensie diagnostycznym w odniesieniu do skal: samooceny, samoakceptacji i nastawienia optymistycznego. 
Druga próba weryfikacji hipotezy o trafności diagnostycznej TPS miała miejsce w 2012 r. na danych z lat 2007-2011. Tym razem jednak za kryterium zewnętrzne przyjęto narzędzie bazujące na innej konceptualizacji teoretycznej poczucia własnej skuteczności. Mianowicie na twierdzeniu A. Bandury o poczuciu skuteczności jako zmiennej sytuacyjnej, zależnej od zadania, które postawimy przed jednostką. Takie podejście wymaga przeprowadzenia badania mikroanalitycznego, czyli odwołania się do sądu osoby badanej na temat możliwości sprostania ściśle zdefiniowanej sytuacji zadaniowej. Mieliśmy się więc dwa pomiary: pomiar TPS oraz pomiar przy pomocy testu sytuacyjnego. Osoby badane poproszono o zakreślenie na czterostopniowej skali odpowiedzi na pytanie o stopień, w jakim poradzą sobie z trudnym, lecz możliwym do wykonania zadaniem. Zrobiono to $w$ odniesieniu do trzech sytuacji: zadanie dotyczące sfery intelektualnej, fizycznej i moralnej. $Z$ tych trzech pomiarów wyprowadzono średnią arytmetyczną jako interwałowy wskaźnik poczucia skuteczności. Wyniki te skorelowano z wynikami TPS 223 osób badanych losowanych z populacji generalnej. Współczynnik Pearsona oszacowano przy $\mathrm{p}<.05$ na poziomie $\mathrm{r}=.64$, uznając go za wysoki wskaźnik korelacji pomiędzy wyżej wymienionymi zmiennymi.

Prace nad weryfikacją trafności prognostycznej prowadzono trzy razy: w 2007 r., 2010 r. i 2012 r. Zawsze dokonywano dwóch pomiarów na jednej próbce w odstępach trzytygodniowych, uzyskując (odpowiednio) następujące wyniki: $\mathrm{r}=.92 ; .94 ; .89$, przy $\mathrm{p}<.05$ i N=220. Można przyjąć, że TPS jest narzędziem o wysokiej stałości, pozwalającym na prognozowanie działania osób badanych.

Pomiary weryfikujące trafność teoretyczną TPS wykonaliśmy w 2006 r. i 2012 r. Zastosowaliśmy dwie metody: metodę czynnikową/skupieniową oraz metodę sprawdzania różnic międzygrupowych. W 2006 r. badania przeprowadziliśmy na próbce 150 nauczycieli szkół gimnazjalnych i licealnych. W przypadku trafności czynnikowej i skupieniowej sformułowaliśmy hipotezę o występowaniu dwóch czynników (dwóch skupień) grupujących pozycje testu jako wskaźników zasobów motywacyjnych i poznawczo-działaniowych. Na te pierwsze składają się: umiejętność odraczania gratyfikacji, wiara we własne siły, motywacja rozwojowa i wytrwałość w działaniu, a więc pozycje: 2 , $4,5,7,9,15,16,17$. Natomiast zasoby poznawczo-działaniowe budują takie zmienne, jak: umiejętność przekładania celów na program działania, odporność na frustrację i stres, poczucie sprawstwa oraz wewnątrzsterowność, zoperacjonalizowane w pozycjach: $1,3,6,8,10,11,12,13,14$. Weryfikacja tej hipotezy wymagała przeprowadzenia analizy czynnikowej lub analizy skupien. 
Przeprowadziliśmy obie analizy. Zmiennymi wprowadzonymi do modelu analizy czynnikowej były pozycje testu. Dane te zostały poddane eksploracyjnej analizie czynnikowej (EFA), szczególnie przydatnej w sytuacjach, gdy zasoby zmienności wspólnej są niskie, a tak jest najczęściej w przypadku testów i skal (Ferguson, Takane 2003, s. 560-561). Przeprowadzone obliczenia pozwoliły wyodrębnić dwa czynniki, które pokazuje tabela 2 .

Tabela 2. Czynniki i ładunki czynnikowe poszczególnych pozycji

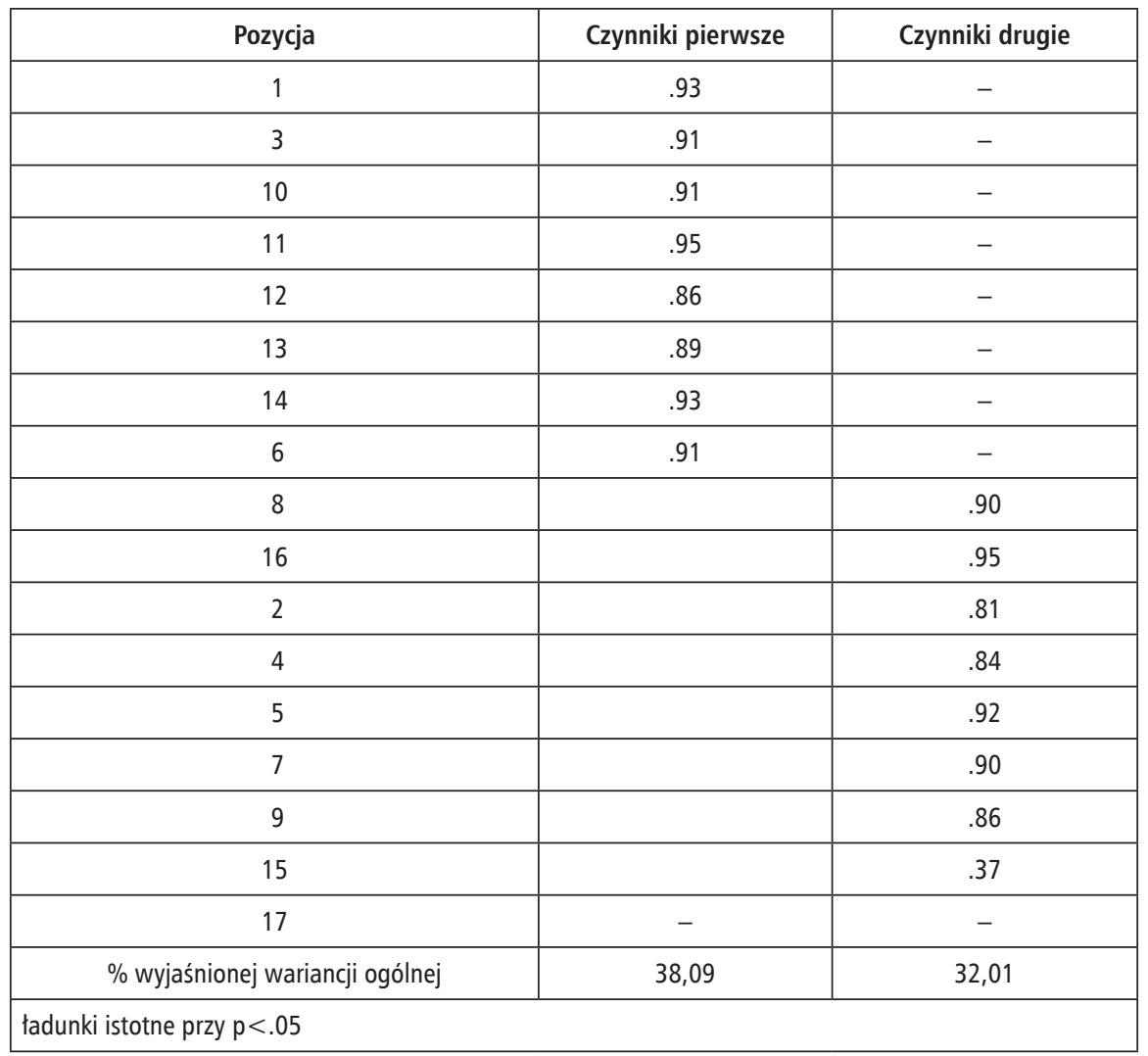

Źródło: badania własne.

Czynnik pierwszy można interpretować jako zasoby poznawczo-działaniowe, a czynnik drugi jako zasoby motywacyjne. Czynnik pierwszy wyjaśnia 38,09\% ogólnej wariancji, a czynnik drugi 32,01\%. Różnica między strukturą hipotetyczną, a otrzymaną dotyczy dwóch kwestii. Po pierwsze, pozycje two- 
rzące „poczucie sprawstwa”, a więc 6 i 8 miały znaleźć się w czynniku zasobów poznawczo-działaniowych. I tak się stało z pozycją 8, lecz pozycja 6 („Granicą wiary we własne siły są informacje o tym, jak nas spostrzegają inni”) współtworzy czynnik zasobów motywacyjnych. Po drugie, pozycja 17 („Gdyby nie to, że niektóre zadania zbyt silnie wystawiały na próbę moją cierpliwość, zakończyłbym je sukcesem"), hipotetycznie składająca się na zasoby motywacyjne, nie uzyskała istotnego statystycznie ładunku w obu czynnikach. Może to oznaczać, że zmienna ta bardzo nisko koreluje z pozostałymi. Przyczyną tego stanu rzeczy mogłaby być niska rzetelność tej pozycji. Wówczas należałoby ją usunąć z puli danych. Nie można jednak z całą pewnością przypisać jej niskiego współczynnika rzetelności, przynajmniej w porównaniu do innych pozycji. Alfa Cronbacha dla tej pozycji nie odstaje od współczynników rzetelności innych pozycji i wynosi .89 . Z powodu zaistniałych okoliczności zdecydowaliśmy się na wykonanie analizy skupień. $Z$ jednej strony posługiwanie się analizą skupień jako metodą weryfikacji wyników analizy czynnikowej nie zawsze jest słuszne, ponieważ analiza czynnikowa pozwala interpretować dane na innym poziomie niż analiza skupień. Ta druga jest bardziej powierzchowna, a samo skupienie bywa traktowane jako skutek, podczas gdy czynnik można interpretować w kategoriach przyczyny (Zakrzewska 1994, s. 26). Warto jednak podkreślić, że powyżej zastosowaliśmy eksploracyjną analizę czynnikową, która testuje liniowe układy zmiennych, a nie kowariancje w ujęciu przyczynowym. Ten fakt upodobnia naszą analizę do metody skupień na tyle, że niekoniecznie narażamy się na zarzut bezzasadności stosowania obu podejść.

Wyniki hierarchicznej analizy skupień wykonanej na tych samych danych, co analiza czynnikowa, metodą $\mathbf{k}$ - średnich powiązań międzygrupowych (Noworol 1989) pokazuje tabela 3 i wykres 1.

Tabela 3. Wyniki analizy skupień: elementy skupienia i współczynniki skupienia

\begin{tabular}{|l|c|c|c|c|c|c|c|c|c|}
\hline \multicolumn{10}{|c|}{ skupienie I } \\
\hline pozycja & 1 & 3 & 10 & 11 & 12 & 13 & 14 & 6 & - \\
\hline $\begin{array}{l}\text { współczynnik } \\
\text { skupienia }\end{array}$ & .467 & .467 & .410 & .410 & .467 & .410 & .344 & .410 & - \\
\hline \multicolumn{8}{|c|}{ skupienie II } \\
\hline pozycja & 8 & 16 & 2 & 4 & 5 & 7 & 9 & 15 & 17 \\
\hline $\begin{array}{l}\text { współczynnik } \\
\text { skupienia }\end{array}$ & .561 & .294 & .580 & .704 & .437 & .665 & .773 & .997 & .981 \\
\hline
\end{tabular}

Źródło: badania własne. 


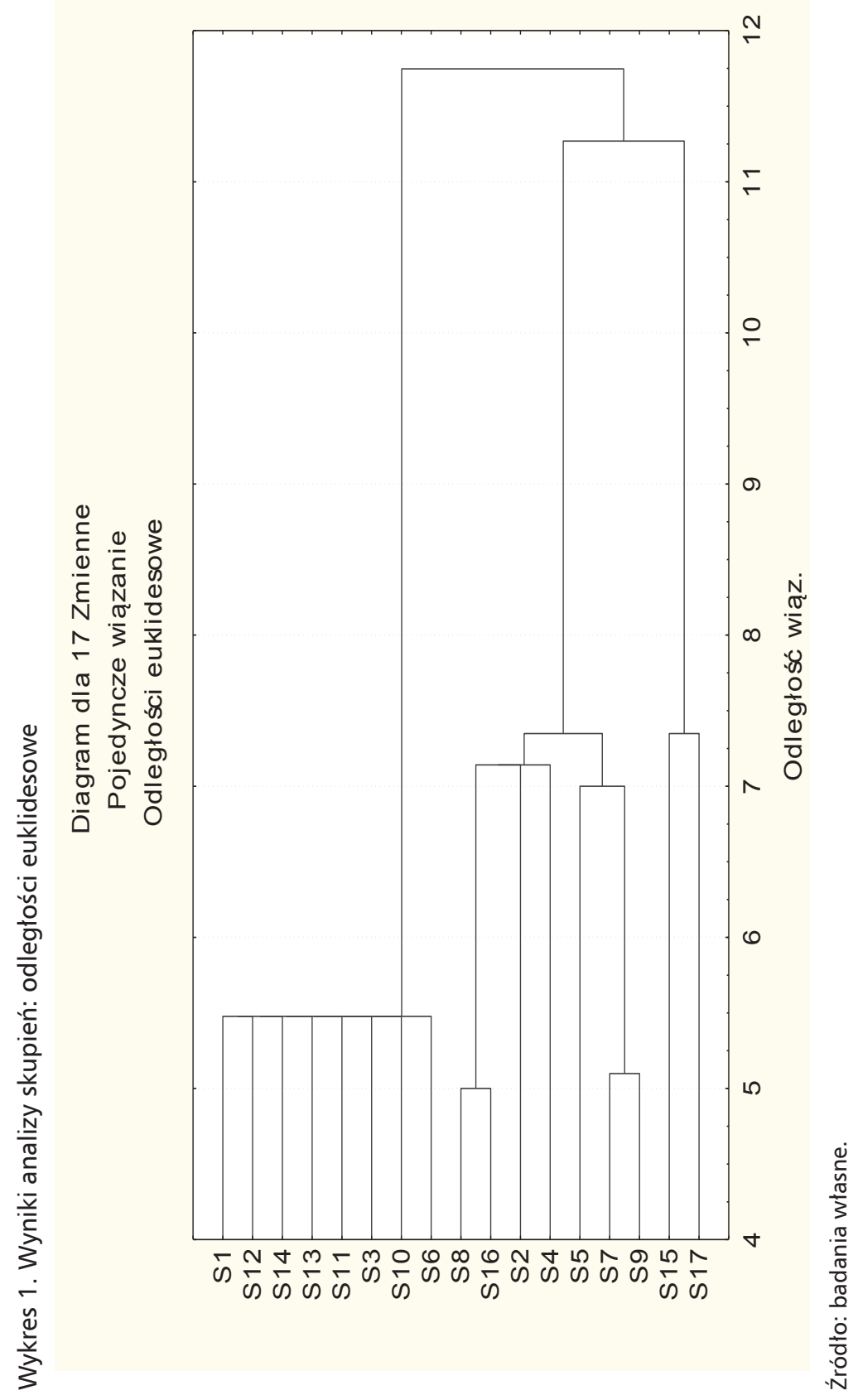


Zamieszczone powyżej dane generalnie potwierdzają wyniki analizy czynnikowej. Powstały dwa skupienia odpowiadające w sensie teoretycznym zasobom poznawczo-działaniowym (skupienie pierwsze) oraz motywacyjnym (skupienie drugie). Nie zmieniła się sytuacja z pozycją 6 , która także tutaj została przypisana do zasobów motywacyjnych. I jest to wynik weryfikacji empirycznej, jakiej właśnie dokonaliśmy. Natomiast pozycja 17 znalazła się w skupieniu drugim, a więc współtworzy, zgodnie z podstawami teoretycznymi, zasoby motywacyjne jako subkategorię poczucia własnej skuteczności.

Można zatem powiedzieć, że zarówno struktura czynnikowa, jak i skupieniowa pozytywnie weryfikuje sformułowaną hipotezę. Przesunięcie pozycji 6 przyjęliśmy w 2006 r. jako wynik analiz empirycznych, modyfikujący założenia teoretyczne. Natomiast status pozycji 17 (poza wyłonionymi czynnikami i jednocześnie w obrębie uzyskanych skupień) potraktowaliśmy wtedy jako niewyjaśniony. W 2012 r. wykonana analiza czynnikowa ulokowała - ostatecznie - pozycję 17 w czynniku odtwarzającym zasoby motywacyjne (z ładunkiem .38). Analiza z 2012 r. (na próbce z populacji ogólnej) potwierdziła zatem hipotezę o pierwotnie przyjętej strukturze TPS. Nadal jednak traktujemy ją jedynie jako kryterium weryfikacji podstaw teoretycznych nie zaś punkt wyjścia do budowy skal TPS.

Kolejnym krokiem w 2006 r. było zastosowanie drugiej miary trafności teoretycznej TPS. Do tego celu wykorzystaliśmy metodę sprawdzania różnic międzygrupowych (Brzeziński 1984, s. 192). Zgodnie z przewidywaniami teoretycznymi powinny istnieć statystycznie istotne różnice pomiędzy dwiema grupami badanych, z których jedna charakteryzuje się wysokim poczuciem sprawstwa w działalności edukacyjnej, a druga niskim natężeniem tej zmiennej. Poczucie sprawstwa, o którym tu mowa, jest zmienną definiowaną w kategoriach pozytywnej samooceny oraz dobrze ugruntowanej samowiedzy dotyczącej postrzegania własnych możliwości wpływania na zdarzenia i zmieniania ich biegu (por. Łukaszewski 1984, s. 435). Tak rozumiana zmienna stanowi przedmiot pomiaru w teście Pełnienia Roli Nauczyciela (Rubacha 2000). Ponieważ trafność teoretyczna tego narzędzia została pozytywnie zweryfikowana metodą analizy czynnikowej, zastosowaliśmy je do szacowania trafności teoretycznej Testu Poczucia Skuteczności. Hipoteza zatem brzmiała: pojawią się statystycznie istotne różnice w średnich wynikach poczucia własnej skuteczności pomiędzy badanymi o niskim i wysokim natężeniu poczucia sprawstwa. Ci ostatni uzyskają wyższe średnie poczucia własnej skuteczności niż ci pierwsi. Pozytywna weryfikacja tej hipotezy potwierdza trafność teoretyczną TPS w odniesieniu do poczucia sprawstwa, jednak tylko dla grupy nauczycieli. Analizy takiej nie wykonano dla próbki z populacji ogólnej. 
Tabela 4. Jednoczynnikowa Anova dla zmiennych poczucie sprawstwa oraz poczucie własnej skuteczności

\begin{tabular}{|c|c|}
\hline poczucie sprawstwa & średnie poczucia własnej skuteczności \\
\hline niskie & 1,75 \\
\hline wysokie & 2,43 \\
\hline \multicolumn{2}{|c|}{$\mathrm{F}=74,79 ;$ df grup $=1 ;$ df reszt. $=187, \mathrm{p}<.05$} \\
\hline
\end{tabular}

Źródło: badania własne.

Podsumowując problemy trafności TPS, można przyjąć, że wszystkie wymienione wyżej rodzaje trafności zostały zweryfikowane pozytywnie. Szczególnie ważne jest, że w 2012 r. udało się potwierdzić strukturę czynnikową narzędzia, ponieważ analiza czynnikowa jest najbardziej wiarygodną miarą trafności każdego testu.

\section{Normalizacja}

Ostatnim etapem standaryzacji TPS było przekształcenie wyników surowych na skalę interwałową. Dokonano tego zabiegu w 2006 r. i 2012 r., stosując skalę stenową, która składa się z 10 jednostek obejmujących trzy odchylenia standardowe od średniej (sten $=0,5$ odchylenia standardowego). Podstawą normalizacji z 2006 r. były wyniki badań nad próbką 301 nauczycieli, którzy niemal po połowie reprezentowali obie płcie, stanowiąc przedział wieku 25-65 lat. Natomiast w 2012 r. analizowano wyniki badań próbki z populacji ogólnej i nauczycieli po $\mathrm{N}=472,50 \%$ kobiet i $50 \%$ mężczyzn, w przedziale wieku 17-54 lata - populacja ogólna, i od 26-59 - populacja nauczycieli. Zgodnie z interpretacją M. Nowakowskiej (1970, s. 479) od 10. do 7. stena znajduje się wysokie natężenie poczucia własnej skuteczności, 6 i 5 sten to przeciętne natężenie, a od 4. do 1. niskie. Patrząc na tabelę 4 (2006 r.), można dojść do wniosku, że przesunięcie skali ujawnia najsilniejszą koncentrację badanych na poziomie wyników przeciętnych, potem niskich, na końcu wysokich. Nie jest to zatem test nadmiernie prowokujący do udzielania odpowiedzi zgodnych z kluczem, czyli zawierających wskaźniki silnego poczucia własnej skuteczności. Taka przynajmniej tendencja ujawniła się w nauczycielskiej grupie normalizacyjnej. Biorąc pod uwagę zagrożenie tej zmiennej aprobatą społeczną, należy zauważyć, że w próbce normalizacyjnej nie znaleźli się badani nadmiernie wartościujący osobiste zasoby tworzące poczucie własnej skutecznej. 
Tabela 5. Tymczasowe normy stenowe dla Testu Poczucia Skuteczności

\begin{tabular}{|c|c|c|c|}
\hline wynik surowy & $\begin{array}{c}\text { steny } 2006 \mathrm{r} \text {. } \\
\text { nauczyciele }\end{array}$ & $\begin{array}{l}\text { steny } 2012 \mathrm{r} \text {. } \\
\text { nauczyciele }\end{array}$ & $\begin{array}{c}\text { steny } 2012 \text { r. } \\
\text { populacja ogólna }\end{array}$ \\
\hline 68 & 10 & 10 & 10 \\
\hline 67 & 10 & 10 & 10 \\
\hline 66 & 10 & 10 & 9 \\
\hline 65 & 10 & 9 & 9 \\
\hline 64 & 10 & 9 & 9 \\
\hline 63 & 9 & 9 & 9 \\
\hline 62 & 9 & 9 & 8 \\
\hline 61 & 8 & 8 & 8 \\
\hline 60 & 8 & 8 & 8 \\
\hline 59 & 8 & 8 & 8 \\
\hline 58 & 8 & 8 & 8 \\
\hline 57 & 7 & 8 & 8 \\
\hline 56 & 7 & 8 & 7 \\
\hline 55 & 7 & 7 & 7 \\
\hline 54 & 7 & 7 & 7 \\
\hline 53 & 6 & 7 & 7 \\
\hline 52 & 6 & 7 & 7 \\
\hline 51 & 6 & 7 & 7 \\
\hline 50 & 6 & 7 & 7 \\
\hline 49 & 6 & 7 & 6 \\
\hline 48 & 6 & 6 & 6 \\
\hline 47 & 6 & 6 & 6 \\
\hline 46 & 6 & 6 & 6 \\
\hline 45 & 6 & 5 & 5 \\
\hline 44 & 5 & 5 & 5 \\
\hline 43 & 5 & 5 & 5 \\
\hline 42 & 5 & 4 & 4 \\
\hline 41 & 5 & 4 & 4 \\
\hline 40 & 5 & 4 & 4 \\
\hline 39 & 4 & 4 & 3 \\
\hline 38 & 4 & 4 & 3 \\
\hline 37 & 4 & 3 & 3 \\
\hline 36 & 4 & 3 & 3 \\
\hline 35 & 3 & 3 & 3 \\
\hline 34 & 3 & 3 & 3 \\
\hline 33 & 2 & 3 & 3 \\
\hline 32 & 1 & 3 & 2 \\
\hline 31 & 1 & 2 & 1 \\
\hline 30 & 1 & 1 & 1 \\
\hline 29 & 1 & 1 & 1 \\
\hline 28 & 1 & 1 & 1 \\
\hline$\ldots$ & & & \\
\hline 17 & & & \\
\hline
\end{tabular}

Źródło: badania własne. 
Nieco inaczej wygląda to w obu grupach w 2012 r., gdzie wynik wysoki w populacji ogólnej następuje od 50 punktów surowych, a niski jest do 42 punktów. Przedział wyników przeciętnych zawęził się w stosunku do pomiaru z 2006 r. Podobny rozkład wystąpił w grupie nauczycieli.

\section{Procedura badania i obliczanie wyników}

Badania można wykonywać grupowo lub indywidualnie. Osoba badana przed przystąpieniem do udzielania odpowiedzi musi zapoznać się z instrukcją, która nie podaje prawdziwego celu pomiaru, czego badacz również nie powinien robić. Warto zastanowić się nad równoległym zastosowaniem jednej z dostępnych skal aprobaty społecznej (kłamstwa). Jej użycie pozwoli wyeliminować te osoby spośród badanych, które osiągnęły w tej skali wynik powyżej 6 stena (ostre kryterium) lub 10 stena (kryterium łagodne). Wprawdzie badani z grup standaryzacyjnych nie ujawniali zbyt często wysokich wyników w TPS, warto jednak brać pod uwagę, że treść poszczególnych pozycji dotyczy centralnych obszarów samooceny i może prowokować do prób stawiania siebie w lepszym świetle, niż wynikałoby to ze stanu faktycznego. Wyniki oblicza się przez sumowanie wag odpowiedzi (według klucza), przy czym w części pozycji trzeba odwrócić skalę. Zsumowane wartości porównuje się do zamieszczonych powyżej norm stenowych.

\section{Bibliografia}

Bandura A. (1994), Self-efficacy: Toward a unifying theory of behavioral change, w: R. F. Baumeister (ed.), The self in Social Psychology, Ann Arbor Press, Philadelphia, http://dx.doi.org/10.1037//0033-295X.84.2.191.

Brzeziński J. (1984), Elementy metodologii badań psychologicznych, PWN, Warszawa.

Bussey K., Bandura A. (1999), Social cognitive theory of gender development and differentation, "Psychological Review" No. 4, http://dx.doi.org/10.1037//0033-295X.106.4.676.

Chomczyńska-Rubacha M., Rubacha K. (2006), Poczucie własnej skuteczności nauczycieli. Podstawy teoretyczne, pomiar i obszary badań, „Przegląd Badań Edukacyjnych” 2(3).

Chomczyńska-Rubacha M., Rubacha K. (2007), Pteć kulturowa nauczycieli. Funkcjonowanie w roli zawodowej, Impuls, Kraków.

Cohen L., Manion L., Morrison K. (2005), Research Methods in Education, RoutledgeFalmer, London-New York. 
Ferguson G. A., Takane Y. (2003), Analiza statystyczna w psychologii i pedagogice, PWN, Warszawa.

Guilford J. P. (1988), Rzetelność i trafność pomiarów, w: J. Brzeziński (red.), Problemy teorii, rzetelności, konstrukcji i analizy wyników testów psychologicznych, PTP, Warszawa.

Juczyński Z. (2001), Narzędzia pomiaru w promocji i psychologii zdrowia, Pracownia Testów Psychologicznych PTP, Warszawa.

Kaplan P. S. (1990), Educational Psychology for Tomorrow's Teacher, St. Paul.

Michel W., Schoda Y., Peake P. (1988), The Nature Adolescent Competencies Predicted by Preschool Delay of Gratification, "Journal of Personality and Social Psychology" No. 54, http://dx.doi.org/10.1037//0022-3514.54.4.687.

Nowakowska M. (1970), Polska adaptacja 16-czynnikowego kwestionariusza osobowości R. B. Cattela, „Psychologia Wychowawcza” nr 3.

Noworol C. (1989), Analiza skupień w badaniach empirycznych, PWN, Warszawa.

Obuchowski K. (1985), Adaptacja twórcza, PWN, Warszawa.

Oleś P. (2003), Wprowadzenie do psychologii osobowości, Wydawnictwo Naukowe Scholar, Warszawa.

Pervin L. A., John O .P. (2002), Osobowość. Teoria i badania, Wyd. UJ, Kraków.

Rubacha K. (2000), Petnienie roli nauczyciela a realizacja zadań rozwojowych $w$ okresie wczesnej dorostości, Wydawnictwo UMK, Toruń.

Rubacha K. (2008), Metodologia badań nad edukacja, WAiP, Warszawa.

Strzałecki A. (1989), Twórczość a style rozwiązywania problemów praktycznych. Ujęcie prakseologiczne, Ossolineum, Wrocław.

Zakrzewska M. (1994), Analiza czynnikowa w budowaniu i sprawdzaniu modeli psychologicznych, Wydawnictwo UAM, Poznań.

\section{Spis prac publikujących wyniki badań przy użyciu TPS}

Chomczyńska-Rubacha M., Rubacha K. (2006), Poczucie własnej skuteczności nauczycieli. Podstawy teoretyczne, pomiar i obszary badań, „Przegląd Badań Edukacyjnych” 2(3).

Chomczyńska-Rubacha M., Rubacha K. (2007), Płeć kulturowa nauczycieli. Funkcjonowanie $w$ roli zawodowej, Impuls, Kraków.

Chomczyńska-Rubacha M., Rubacha K. (2008), Poczucie skuteczności a preferowane strategie wychowawcze nauczycieli, w: W. Szulakiewicz (red.), Świat idei edukacyjnych, Wyd. UMK, Torun. 
Rubacha K. (2012), Uogólnione poczucie skuteczności a poczucie skuteczności wychowawczej, „Studia Edukacyjne” nr 21.

Rubacha K. (2012), The sense of pedagogical self-efficacy of parents at varied levels of gender role development, "The New Educational Research" No. 1, Vol. 27.

\section{The Sense of Efficiency Test. Theoretical and psychometric study of Research Tools Workshop of The Committee on Pedagogical Sciences of Polish Academy of Sciences}

\section{Summary}

The article presents theoretical and psychometric study of The Sense of Efficiency Test.

It contains the results of standardizing research reconstruing the process of building a tool and consecutive stages of its empirical verification. It also contains information on the conditions in which The Sense of Efficiency Test should be applied in order to provide a high level of internal relevance for the research. The process of constructing and validating the research lasted 6 years and was based on almost 1,5 thousand random sample. In the period of 2006 through 2012 The Sense of Efficiency Test was applied in various research programmes which continued to test its relevancy and provided material to update the norms for overall population and the population of teachers. 